\title{
ANALISIS LDR DAN NPL PT. BANK NAGARI CABANG PEMBANTU TARUSAN KABUPATEN PESISIR SELATAN
}

\author{
JONI HARDI, JHON FERNOS \\ Akademi Keuangan dan Perbankan "Pembangunan" \\ Jhonfernos@akbpstie.ac.id
}

\begin{abstract}
After carrying out an analysis of the financial statements at the PT. Bank Nagari Sub-Branch of Tarusan, South Coastal District, West Sumatra. In 2013 the company generally experienced an increase and decrease in managing LDR and NPL. Ability in 2014 - 2015 NPL experienced an increase or change that the company in managing LDR in 2014 and 2015 experienced an increase which means that it has a positive influence on PT. Bank Nagari Sub-Branch of South Sumatra Pesisir Regency, West Sumatra. The company's ability to manage NPL is effective because it means it can increase the profits of PT. Bank Nagari Sub-Branch of Tarusan, South Coastal District, West Sumatra.
\end{abstract}

Keywords : Bank, Loan to Deposit Ratio, Non Performing Loan

\section{PENDAHULUAN}

Dalam era globalisasi seperti saat sekarang ini, perekonomian suatu negara sudah menjadi pondasi dalam menghadapi perkembangan yang lebih pesat lagi. Salah satunya adalah pelaksanaan program pembangunan indonesia yang diadakan untuk meningkatkan kualitas hidup masyarakat, tujuan tersebut diwujudkan melalui peningkatan pendapatan dengan berbagai kegiatan yang produktif untuk menciptakan prekonomian yang stabil. Stabilitas perekonomian indonesia membutuhkan ketersedian dan peran serta lembaga keuangan. Pada saat ini terdapat dua jenis lembaga keuangan, yaitu lembaga keuangan bank dan lembaga keuangn bukan bank. Salah satu sarana yang mempunyai peranan yang strategis dalam kegiatan perekonomian adalah lembaga keuangan keuangan bank. Peran strategis tersebut terutama disebabkan oleh fungsi utama perbankan sebagaifinancial intermediary, yaitu sebagai wahana yang dapat menghimpun dan menyalurkan dana masyarakat secara efektif dan efisien.

Perbankan di indonesia bertujuan untuk menunjang pelaksanaan pembangunan nasional dalam rangka meningkatkan pemarataan, pertumbuhan ekonomi, dan stabilitas nasional kearah peningkatan rakyat banyak (Hasibuan, 2007:4).

Arsitektur perbankan indonesia (API) merupakan suatu kerangka dasar sistem perbankan indonesia yang bersifat menyeluruh dan memberikan arah, bentuk, dan tatanan perbankan untuk rentang waktu lima sampai sepuluh tahun kedepan. Visi API (arsitektur Perbankan Indonesia), yaitu menciptakan sistem perbankan yang sehat, kuat, dan efisien guna menjaga kestabilan sistem keuangan nasional dalam rangka mendorong pertumbuhan ekonomi nasional (Triandaru dan Budi santoso, 2008:26).

Perbankan mempunyai peran yang sangat vital dalam pencapaian tujuan nasional yang berkaitan dalam peningkatan dan pemerataan taraf hidup masyarakat 
serta menunjang berjalannya roda perekonomian mengingat fungsinya sebagai lembaga intermediasi, penyelenggara transaksi pembayaran, serta alat tranmisi kebijakan moneter. Perbankan merupakan salah satu penggerak perekonomia suatu negara, karena memiliki fungsi intermediasi atau sebagai perantara pihak yang kelebihan dana (surplus unit) dengan pihak yang kekurangan dana (defisit unit). Fungsi intermediasi ini akan berjalan dengan baik apabila masyarakat memiliki kepercayaan terhadap bank (Yuliani,

2007). Dana yang telah dihimpun kemudian akan disalurkan ke masyarakat dalam berbagai bentuk aktivitas produktif, sehingga bank sekaligus berperan sebagai penggerak perekonomian masyarakat itu sediri.Perbankan di indonesia telah diatur dalam undang-undang RI no. 10 tahun 1998 tentang perubahan atas undang - undang RI no. 7 tahun 1992, bahwa bank adalah badan usaha yang menhimpun dana dari masyarakat dalam bentuk simpanan dan menyalurkan kemballi kepada masyarakat dalam bentuk kredit dan atau bentuk-bentuk lainya dalam rangka meningkatkan taraf hidup rakyat banyak. Hal ini tampak pada kegiatan pokok bank yakni menerima simpanan dari masyarakat dalam bentuk tabungan, giro, dan deposito berjangka, serta menyalurkan kredit kepada pihak yang memerlukan dana (Standar Akuntansi keuangan, 2010).

Fungsi bank sangat krusial bagi perekonomian suatu negara. Oleh karena itu, keberadaa aset bank dalam bentuk kepercayaan masyarakat sangat penting dijaga untu meningkatkan efisiensi penggunaan bank dan efisiensi intermediasi. Kepercayaan masyarakat

juga diperlukan karena bank tidak memiliki uang tunai yang cukup atau alat likuid untuk membayar kewajiban kepada seluruh nasabahnya dalam waktu bersamaan.

Institusi perbankan yang beroperasi di indonesia meliputi 3 jenis yaitu bank sentral, bank umum dan BPR (Bank perkreditan Rakyat). Bank sentral yang dimaksud adalah bank indonesia. Bank indonesia adalah lembaga negara yang independen dalam melaksanakan tugas dan wewenangnya, bebas dari campur tangan pemerintah dan atau pihak lainya, kecuali untuk hal-hal yang secara tegas diatur dalam undang-undang. Bank senteral memiliki fungsi dalam penciptaan uang, mendukung kelancaran mekanisme pembayaran, penghimpun dana dari masyarakat, mendukung kelancaran transaksi internasional, penyimpanan barang-barang berharga dan pemberian jasa lainyaBank umum adalah bank yang melaksanakan kegiatan usaha secara konvensional atau berdasarkan prinsip syariah yang dalam kegiatanya memberikan jasa dalam lalu lintas pembayaran. Bank umum memiliki fungsi dalam menghimpun dana (funding), menyalurkan dana (lending) dan memberikan jasa-jasa bank lainya.

Bank Perkreditan Rakyat (BPR)adalah lembaga keuangan yang menerima simpanan hanya dalam bentuk deposito berjangka, tabungan atau dalam bentuk lainya yang di persamakan dan menyalurkan dana sebagaimana usaha bank perkreditan ranknyat merupakan salah satu jenis bank yang melayani pengusaha mikro, kecil dan menengah dengan lokasi yang pada umumnya dekat dengan masyarakat yang membutuhkannya.

Fungsi bank perkreditan raknyat (BPR) hanya skedar menyalurkan kredit kepada pengusaha mikro, kecil dan menengah, tetapi juga menerima simpangan dari masyarakat.

Rendahnya kualitas perbankan antara lain tercermin dari lemahnya kondisi 
internal sektor perbankan, lemahnya manajemen bank, moral sumber daya manusia (SDM), serta belum efektifnya pengawasan yang dilakukan oleh bank indonesia (BI) kuantitas bank yang banyak menciptakan persaingan yang semakin ketat dan kinerja bank yang menjadi rendah karena ketidak mampuan bersaing di pasar, sehingga banyak bank yang sebenarnya kurang sehat atau bahkan tidak sehat secara financial.

Analisis laporan keuangan merupakan suatu teknik analisa yang dalam banyak hal mampu memberikan petunjuk atau indikator atau gejala gejala yang timbul di sekitar kondisi yangt melingkupinya. Menurut Harahap (2002:190), pengertian analisis laporan keuangan adalah sebagai berikut:"Menguraikan pos-pos laporan keuangan menjadi unit informasi yang lebih kecil dan melihat hubunganya yang bersifat signifikan atau yang mempunyai makana antara satu dengan yang lain baik antara data kuantitatif maupun data non kuantitatif dengan tujuan untuk mengetahui kondisi keuangan lebih dalam yang sanagat penting dalam proses penghasilan keputusan yang tepat."

Loan to Deposit Ratio (LDR) merupakan rasio antara seluruh jumlah kredit yang diberikan oleh bank dengan dana yang diterima oleh bank. Ldr dapat. LDR juga berfungsi untuk mengukur kemampuan bank untuk memenuhi kewajiban keuangan yang harus dipenuhi. Kewajiban tersebut berupa call money yang harus dipenuhi pada saat adanya kewajiban kliring, yang sepenuhnya dilakukan dari aktiva lancar yang dimiliki perusahaan (Suyono, 2005 dan pransnanugraha,2007).

Non Performing Loan (NPL) adalah debitur atau kelompok debitur yang masuk dalam golongan kurang lancar, diragukan, macet dari golongan kredit, hendaknya selalu di ingat bahwa perubahan pengolongan kredit dari kredit lancar menjadi NPL adalah secara berharap melalui proses penurunan kualitas kredit.

Nilai NPL mencerminkan risiko kredit, semakin kecil NPL semakin kecil pula risiko kredit yang ditanggung bank. Bank dengan NPL yang tinggi akan memperbesar biaya baik pencadangan aktiva produktif maupun biaya lainya, sehigga berpotensi terhadap kerugian bank (mawardi, 2005).

Tabel 1.1

Perkembangan LDR dan NPL PT. Bank Nagari Cabang Pembantu TarusanKabupaten Pesisir Selatan Sumatera Barat

Tahun 2013 - 2015

\begin{tabular}{cccccc}
\hline No & Tahun & LDR & $\begin{array}{c}\text { Perubahan } \\
(\boldsymbol{\%})\end{array}$ & NPL & $\begin{array}{c}\text { Perubahan } \\
(\boldsymbol{\%})\end{array}$ \\
\hline 1 & 2013 & 9,0036984 & $-0,25 \%$ & 0,2480 & $0,92 \%$ \\
2 & 2014 & 6,717845 & $-0,014 \%$ & 0,01793 & $-0,66 \%$ \\
3 & 2015 & 6,61853 & $-0,26 \%$ & 0,01783 & $-0,92 \%$ \\
\hline & TOTAL & $16,383,396$ & & 0,28376 & \\
\hline
\end{tabular}

Sumber : Bank Nagari Cabang Pembantu Tarusan, data diolah

PT. Bank Nagari Cabang Pembantu Tarusan mengalami penurunan dan peningkatan pada LDR dan NPL

Berdasarkan latar belakang yang telah dijelaskan, perumusan masalah adalah bagaimana analisis loan to deposit ratio dan loan performing loan PT BankNagari Cabang Pmebantu Tarusan dan tujuan penelitian untuk mengetahui analisis loan to deposit ratio 
dan non performing loan PT .Bank Nagari Cabang Pembantu Tarusan

\section{LANDASAN TEORI}

Bank dalam menjalankan usahanya menhimpun dana dari masyarakat dan menyalurkan kembali kepada masyarakat. Sehubungan dengan fungsi penghimpunan dana ini, bank sering juga disebut lembaga kepercayaan. Sejalan dengan

karakteristik usahanya tersebut, maka bank merupakan suatu segmen usaha yang kegiatannya banyak diatur oleh pemerintah. Pengaturan secara ketat oleh pengusaha moneter terhadap kegiatan perbankan ini tidak terlepas dari perannya dalam pelaksanaan kebijakan moneter. Bank dapat mempengaruhi jumlah uang beredar yang merupakan salah satu sarana pengaturan oleh pengusaha moneter dengan mengunakan berbagai piranti kebijakan moneter.

Bank secara sederhana dapat diartikan sebagai lembaga keuangan yang kegiatannya menghimpun dana dari masyarakat dan menyalurkannya kembali kepada masyarakat serta memberikan jasa bank lainnya. Definisi bank menurut UU perbankan No. 7 tahun 1992 sebagaimana telah diubah dalam UU perbankan No. 10 tahun 1998 menyebutkan bahwa: "Bank adalah badan usaha yang menghimpun dana dari masyarakat dalam bentuk simpanan dan menyalurkannya kepada masyarakatdalam bentuk kredit dan atau dalam bentuk lainnya dalam rangka meningkatkan taraf hidup rakyat banyak".

Pengertian yang lebih teknis dapat ditemukan pada standar akutansi keuangan (PSAK) dan surat keputusan mentri keuangan RI Nomor 792 tahun

1990. Pengertian bank menurut PSAK nomor 31 dalam standar Akutansi keuangan (1993:31):

"Bank adalah suatu lembaga yang berperan sebagai perantara keuangan antara pihak - pihak yang memerlukan dana, serta sebagai lembaga yang berfungsi memperlancar lalu lintas pembayaran".

Sedangkan berdasarkan SK mentri keuangan RI nomor 792 tahun 1990, pengertian bank adalah :

"Bank merupakan suatu badan yang kegiatannya di bidang keuangan melakukan penghimpunan dan penyaluran dana kepada masyarakat terutama guna membiayai investasi perusahaan”.

Dari beberapa pengertian diatas maka disimpulkan bahwa pada hakekatnya bank merupakan suatu lembaga keuangan yang berfungsi sebagai perantara atau mediator bagi peredaran lalu lintas uang yaitu dengan cara menghimpun dana dari masyarakat

yang kelebihan dana dalam bentuk simpanan lalu menyalurkan kembali dana tersebut kepada masyarakat yang memerlukan dan dalam bentuk pinjaman.

\section{Pengertian Bank Konvensional}

Bank konvensional merupakan bank yang melaksanakan kegiatan usaha secara konvensional yang dalam kegiatannya memberikan jasa dalam lalu lintas pembayaran. Menurut Undang-undang Nomor 10 Tahun 1998

Bank Konvensional adalah bank yang melaksanakan kegiatan usaha secara konvensional yang dalam kegiatannya memberikan jasa dalam lalu lintas pembayaran.

Martono (2002) menjelaskan prinsip konvensional yang digunakan bank konvensionalmenggunakan dua metode, yaitu :

1. Menetapkan bunga sebagai harga, baik untuk produk simpanan seperti tabungan, 
deposito berjangka, maupun produk pinjaman (kredit)yang diberikan berdasarkan tingkat bunga tertentu.

2. Untuk jasa-jasa bank lainnya, pihak bank menggunakan atau menerapkan berbagai biaya dalam nominal atauprosentase tertentu. Sistem penetapan biaya ini disebut fee based

Pada bank konvensional, kepentingan pemilik dana (deposan) adalah memperoleh imbalan berupa bunga simpanan yang tinggi, sedang kepentingan pemegang saham adalah diantaranya memperoleh spread yang optimal antara suku bunga simpanan dan suku bunga pinjaman (mengoptimalkan interest diference). Dilain pihak kepentingan pemakai dana (debitor) adalah memperoleh tingkat bunga yang rendah (biaya murah). Dengan demikian terhadap ketiga kepentingan dari tiga pihak tersebut terjadi antagonisme yang sulit diharmoniskan. Dalam hal ini bank konvensional berfungsi sebagai lembga perantara saja.

Tidak adanya ikatan emosional yang kuat antara pemegang saham, pengelola Bank dan Nasabah karena masing-masing pihak mempunyai keinginan yang brtolak belakang.

1. Penentuan suku bunga dibuat pada waktu akad dengan pedoman harus selalu untung pihak bank

2. Besarnya prosentase berdasarkan pada jumlah uang (modal) yang dipinjamkan penentuan suku bunga dibuat pada waktu akad dengan pedoman harus selalu untung untuk pihak bank

3. Jumlah pembayaran bunga tidak mengikat meskipun jumlah keuntungan berlipat ganda saat keadaan ekonomi sedang baik

4. Eksistensi bunga diragukan kehalalannya oleh semua agama termasuk agama islam

5. Pembayaran bunga tetap seperti yang dijanjikan tanpa pertimbangan

Fungsi Bank

Fungsi bank secara umum adalah menghimpun dana dari masyarakat luas (funding) dan menyalurkan dalam bentuk pinjaman atau kredit (lending) untuk berbagai tujuan. Menurut Y. Sri Susilo, Sigit Triandaru, dan A Totok Budi Santoso (2006) yaitu sebagai berikut :

1. Agent of trust

Dasar utama kegiatan perbankan adalah trust atau kepercayaan, baik dalam hal menghimpun dana maupun penyaluran dana.

2. Agent of Development

Kelancaran kegiatan investasi, distribusi, konsumsi ini tidaklain adalah kegiatan pembangunan perokonomian masyarakat.

3. Agent of Service

Selain menghimpun dan menyalurkan dana, bank jugamemberikan penawaran jasa - jasa perbankan yang lain kepda masyarakat seperti jasa pengiriman uang, jasa penitipan barang berharga dan lain sebagainya.

\section{Pengertian Laporan Keuangan}

Laporan Keuangan adalah catatan informasi keuangan suatu perusahaan pada suatu periode akutansi yang dapat digunakan untuk mengambarkan kinerja perusahaan tersebut. Menurut Standar Akutansi Keungan (SAK) laporan keuangan merupakan bagian dari proses pelaporan keuagan yang lengkap.

Umumnya laporan keuangan dikelompokan menjadi 4 bagian yakni laporan laba rugi (L/B), neraca, laporan arus kas dan laporan perubahan modal. 
Pengertian Loan to Deposit Ratio (LDR)

Loan to Deposit Ratio (LDR) merupakan rasio antara seluruhjumlah kredit yang diberikan oleh bank dengan dana yang diterima oleh bank. LDR dapat dirumuskan sebagai berikut (Surat Edaran Bank Indonesia Nomor 3/30DPNP tanggal 14 Desember 2001):

\section{LDR= Jumlah Kredit yang Diberikan $\times 100 \%$ Total Dana Pihak Ketiga}

Menurut veithzal Rivai (2006) LDR menyatakan seberapa jauh kemampuan bank dalam membayar kembali penarikan dana yang dilakukan masyarakat dengan mengandalkan kredit yang diberikan sebagai sumber likuiditasnya. Artinya seberapa jauh pemberian kredit kepada nasabah kredit dapat mengimbangi kewajiban bank untuk dapat segera memenuhi permintaan deposan yang ingin menarik kembali dananya yang telah digunakan oleh bank untuk memberikan kredit.

LDR merupakan rasio yang mengukur kemampuan bank untuk memenuhi kewajiban keuangan yang harus dipenuhi. Kewajiban tersebutberupa call money yang harus dipenuhi pada saat adanya kewajiban kliring, yang pemenuhanya dilakukan dari aktiva lancar yang dimiliki perusahaan (Suryono, 2005 dan Prasnanugraha, 2007).

LDR digunakan untuk menilai kemampuan suatu bank dengan cara membagi jumlah kredit dengan jumlah dana. LDR merupakan rasio yang menunjukan kemampuan suatu bank dalam menyediakan dana kepada debiturnya dengan modal yang dimiliki oleh bank maupun dana yang dapat dikumpulkan dari masyarakat (Almilia, Hardiningtyas, 2005 dan Ponco, 2008).

Besarnya LDR mengikuti perkembangan kondisi ekonomi indonesia, batas aman LDR suatu bank secara umum adalah sekitar 78

- 100\% (peraturan Bank Indonesia Nomor 12/PBI/2010). Besar kecilnya rasio LDR suatu bank akan mempengaruhi profitabilitas banktersebut. Semakin besar jumlah dana yang disalurkan kepada nasabah dalam bentuk kredit maka jumlah dana yang menganggur berkurang dan penghasilan bunga yang diperoleh akan menigkat.

Pengertian Non Performing Loan ( NPL )

Non Performing Loan (NPL) adalah debitur atau kelompok debitur yang masuk dalam golongan kurang lancar, diragukan, macet, dari 5 golongan kredit, hendaknya selalu diingat bahwa perubahaan penggolongan kredit dari kredit lancar menjadi NPL adalah secara bertahap melalui proses penurunan kualitas kredit.Sesuai SE No.3/30/DPNP tanggal 14 Desember 2001 NPL dapat dirumuskan sebagai berikut:

\section{NPL $=\underline{\text { Total NPLx }} 100 \%$ Total Kredit}

Risiko kredit didefinisikan sebagai risiko yang dikaitkan dengan kemungkinan kegagalan nasabah membayar kewajibannya atau risiko 
dimana debitur tidak dapat melunasi hutangnya. Salah satu risiko yang muncul akibat semakin kompleknya kegiatan perbankan adalah munculnya NPL yang semakin besar. Atau dengan kata lain semakin besar skala operasi suatu bank maka aspek pengawasan semakin menurun, sehingga NPL semakin besar atau risiko kredit semakin besar (Mawardi, 2005).

NPL adalah perbandingan rasio kredit bermasalah dengan total kredit. NPL yang baik adalah NPL yang memiliki nilai dibawah 5\%. Dikatakan sehat jika jumlah kredit tidak lancar dibawah 5\% dari total kredit yang di berikan kepada nasabah. Dikatakan tidak sehat jika jumlah kredit tidak lancar diatas 5\% dari total kredit yang diberikan kepada nasabah.

Nilai NPL mencerminkan risiko kredit, semakin kecil NPL semakin kecil pula risiko kredit yang ditanggung bank. Bank dengan NPL yang tinggi akan memperbesar biya baik pencadangan aktiva produktif maupun biaya lainya, sehingga berpotensi terhadap kerugian bank (Mawardi, 2005).

Penyebab terjadinya Non Performing Loan menurut Dendawijaya (2004), kemacetan fasilitas kredit disebabkan oleh 2 faktor, yaitu:

1. Dari pihak perbankan

Dalam hal ini pihak analis kredit kurang teliti baik dalam mengecek kebenaran dan keaslian dokumen maupun salah dalam menghitung rasio-rasio yang ada. Akibatnya, apa yang seharusnya terjadi, tidak diprediksi sebelumnya.

2. Dari pihak nasabah

Kemacetan kredit yang disebabkan nasabah diakibatkan 2 hal, yaitu:

a. Adanya unsur kesengajaan

Adanya unsur tidak sengaja implikasi dari Non Performing Loan.

Dampak dari keberadaan Non Performing Loan dalam jumlah besar tidak hanya berdampak pada bank yang bersangkutan, tetapi juga meluas dalam cakupan nasional apabila tidak dapat ditangani dengan tepat. Mita Puji Utari (2011) dan Dendawijaya (2003) mengemungkakan dampak Non Performing Loan yang tidak wajar sebagai berikut:

1) Hilangnya kesempatan memperoleh kesempatan pendapatan (income) dari kredit yang diberikan, sehingga mengurangi laba dan mengurangi kemampuan untuk memberikan kredit.

2) Rasio kualitas aktiva produktif menjadi semakin besar yang menggambarkan situasi memburuk.

b. Adanya unsur tidak disengaja

Adanya unsur tidak disengaja umum nya disebabkan oleh musibah, misalnya kebakaran, bencana alam, krisis moneter

\section{METODE PENELITIAN}

digunakan

Dalam pengumpulan data dan bahan untuk melakukan penelitian ini,

1. Metode Pengumpulan Data

a. Studi Lapangan (Field Research)

Peninjauan langsung ke objek penelitian dipilih untuk meneliti hasil data primer. Penelitian langsung kelapangan ini isakan dapat membantu penulis untuk melengkapi data yang diperlukan. Adapun cara riset lapangan ini adalah dengan mewawancarai pihak-pihak yang berkepentingan, dalam hal ini adalah perusahaan atau instansi yang terkait.

b. Studi kepustakaan (Library Research ) 
Penelitianyang dilakukan kepustaka. Beberapa buku-buku ilmiah dan tulisantulisan yang berhubungan dengan pembahasan yang dilakukan.

2. Metode Analisa Data

Dalam menganalisis data, penulis mengunakan analisis data kuantitatif sebagai metode penelitian yang menjelaskan secara deskriptif mengenai rasio LDR dan NPL Pada PT. Bank Nagari Cabang Pembantu Tarusan

Metode analisis data ditinjau dari dua segi yang berbeda yaitu antara teori dan praktek yang perlu diterapkan sehingga dapat diketahui sejauh man pelaksanaanya, apakah perbedaan timbul yang menyangkut prinsip dasar konsep itu sendiri. Pertanyaan itu akan terjawab selanjutnya dari hasil analisis itu digunakan sebagai dasar pengmbilan kesimpulan dan saran.

\section{HASIL DAN PEMBAHASAN}

Pengertian Loan to Deposit Ratio (LDR) merupakan rasio yang mengukur kemampuan bank untuk memenuhi kewajiban keuangan yang harus dipenuhi. Kewajiban tersebut berupa call money yang harus dipenuhi pada saat adanya kewajiban kliring, yang pemenuhanya dilakukan dari aktiva lancar yang dimiliki perusahaan (Suryono, 2005 dan Prasnanugraha, 2007).Sedangkan menurutAlmilia, Hardiningtyas, 2005 dan Ponco, 2008

LDR digunakan untuk menilai kemampuan suatu bank dengan cara membagi jumlah kredit dengan jumlah dana. LDR merupakan rasio yang menunjukan kemampuan suatu bank dalam menyediakan dana kepada debiturnya dengan modal yang dimiliki oleh bank maupun dana yang dapat dikumpulkan yang diterima oleh bank dari masyarakat.

LDR dapat dirumuskan sebagai berikut sebagai berikut (Surat Edaran Bank Indonesia Nomor 3/30DPNP tanggal 14 Desember 2001):

\section{LDR = Jumlah Kredit yang Diberikan $x$ 100\% Total Dana Pihak Ketiga}

Tabel 3.1

Perhitungan Loan to Deposit Ratio Tahun 2013 - 2015

\begin{tabular}{ccccc}
\hline No & Tahun & $\begin{array}{c}\text { Jumlah Kredit } \\
(1)\end{array}$ & $\begin{array}{c}\text { Dana Pihak Ketiga } \\
(2)\end{array}$ & $\begin{array}{c}\text { (1:2)x100 } \\
\%\end{array}$ \\
\hline 1. & 2013 & Rp311.731.535.651 & Rp34.622.609.572 & $9,003 \%$ \\
2. & 2014 & Rp862.917.333.331 & Rp128.451.513.965 & $6,72 \%$ \\
3. & 2015 & Rp1.178.518.983.026 & Rp178.063.677.817 & $6,62 \%$
\end{tabular}

Sumber : Data diolah

NPL adalah debitur atau kelompok debitur yang masuk dalam golongan kurang lancar, diragukan, macet, dari 5 golongan kredit, hendaknya selalu diingat bahwa perubahaan penggolongan kredit dari kredit lancar menjadi NPL adalah secara bertahap melalui proses penurunan kualitas kredit. Sesuai SE No.3/30/DPNP tanggal 14 Desember 2001 NPL dapat dirumuskan sebagai berikut: 


\section{NPL $=\underline{\text { Total Non Performing Loan }} \times 100 \%$ \\ Total Kredit}

Tabel 3.2

Non performing Loan (NPL)

Tahun 2013 - 2015

\begin{tabular}{|l|l|l|c|c|}
\hline No & Tahun & Jumlah NPL & Jumlah Kredit & NPL \% \\
& & $(1)$ & $(2)$ & $(1: 2) \times 100 \%$ \\
\hline & 2013 & Rp 77.317.150 & Rp311.731.535.651 & $0,2480 \%$ \\
\hline & 2014 & Rp 15.417.793.201 & Rp862.917.333.331 & $0,01793 \%$ \\
\hline & 2015 & Rp 21.006.235.816 & Rp1.178.518.983.02 & $0,01783 \%$ \\
& & & 6 & \\
\hline
\end{tabular}

Sumber : Data diolah

Angka diatas memberikan arti bahwa setiap RP.1 nilai hutang, 9,003\% diantaranya (atau Rp 0,09003) akan menghasilkan pendapatan. Perludipahami bahwa ratio ini merefleksikan: harga pokok penjualan, beban - beban operasi, beban keuangan ( beban bunga) keuangan.Angka diatas memberikan arti bahwa setiap RP.1 nilai hutang, 6,72 \% diantaranya (atau $\mathrm{Rp} 0,062$ ) akan menghasilkan pendapatan. Perlu dipahami bahwa ratio ini merefleksikan: harga pokok penjualan, beban - beban operasi, beban keuangan ( beban bunga) keuangan.Angka diatas memberikan arti bahwa setiap RP.1 nilai hutang, 6,62 \% diantaranya (atau Rp 0,0662) akan menhasilkan pendapatan. Perlu dipahami bahwa ratio ini merefleksikan: harga pokok penjualan, beban - beban operasi, beban keuangan ( beban bunga) keuangan.NPL pada PT.Bank Nagari cabang pembantu tarusan sumatera barat nilainya cukup baik 0,2480\% , karena NPL yang baik adalah NPL yang memiliki nilai dibawah 5\%.

NPL pada PT.Bank Nagari cabang pembantu tarusan sumatera barat nilainya cukup baik $0,017893 \%$, karena NPL yang baik adalah NPL yang memiliki nilai dibawah $5 \%$.

NPL pada PT.Bank Nagari cabang pembantu tarusan sumatera barat nilainya cukup baik $0,01783 \%$, karena NPL yang baik adalah NPL yang memiliki nilai dibawah $5 \%$.

\section{SIMPULAN}

Setelah melaksanakan analisa terhadap laporan keuangan pada PT.Bank Nagari Cabang Pembantu Tarusan Kabupaten Pesisir Selatan Sumatera Barat penulis dapat menarik kesimpulan :

1. Pada tahun 2013 Secara umum efisen perusahaan mengalami kenaikan dan penurunan dalam mengelola LDR dan NPL.

2. Kemampuan perusahaan dalam mengelola LDR pada tahun 2014 dan 2015 mengalami penigkatanyang artinya mmpunyai pengaruh positif pada PT. Bank Nagari Cabang Pembantu Tarusan Kabupaten Pesisir Selatan Sumatera 
Barat.

3. Kemampuan perusahaan dalam mengelola NPL efektif karea pada tahun 2014 - 2015 NPL mengalami kenaikan atau perubahan yang artinya dapat meningkatkan keuntungan PT. Bank Nagari Cabang Pembantu Tarusan Kabupaten Pesisir Selatan Sumatera Barat.

\section{DAFTAR PUSTAKA}

Bank Indonesia. 1992. Undang -Undang. Nomor 7 Tahun 1992. Tentang Perbankan. Jakarta. Bank Indonesia.1992. Undang - Undang Nomor 10 Tahun 1998. Tentang Perbankan.Jakarta.

Dendawijaya Lukman. 2003. Manajemen Perbankan, EdisiKedua. Jakarta: Ghalia Indonesia.

Fernos, J. (2017). Analisis Rasio Profitabilitas Untuk Mengukur Kinerja (Studi Kasus Pada PT. Bank Pembangunan Daerah Provinsi Sumatera Barat) Jurnal Pundi.

Hadayani, M., \& Marlius, D. (2017). Analisis Tingkat Kesehatan PT. BPR Batang Kapas. https://doi.org/10.31227/osf.io/bq48z

Hasibuan, Melayu. 2007. Dasar - Dasar Perbankan. Jakarta: PT Bumi Aksara. Ikatan Akuntansi Keuangan Indonesia. 2010. Standar Akuntansi Keuangan.

Putri, Y. A., \& Marlius, D. (2018). Analisis Tingkat Kesehatan Bank Pada PT. Bank Perkreditan Rakyat (BPR) Jorong Kampuang Tangah Pariaman Cabang Padang. https://doi.org/10.31227/osf.io/r98pv

Ponco, Budi. 2008. "Analisis Pengaruh CAR,NPL,BOPO, NIM dan LDR Terhadap ROA ( Studi Kasus Pada Perusahaan Perbankan yang Terdaftar di Bursa Efek Indonesia P eriode 2004 - 2007 )". Tesis program Studi Magister Manajemen program pascasarjana Universitas Diponogoro. Terpublikasi Melalui Link: (http://eprints.undip.ac.id/16854/1/BUDIPONCO.pdf,diaksestanggal:20 september 2014 ).

Triandaru,Sigit dan Toko Budisantoso. 2008.Bank dan Lembaga Keuangan lain. Jakarta:Selemba Empat.

Yuliani.2007.'Hasibuan Efisiensi Operasional dengan kinerja profitabilitas pada sektor perbankan yang go public di bursa efek jakarta".jurnal manajemen dan bisnis sriwijaya. Vol.5 (10). 